\title{
EFFECT OF SUB CHRONIC ADMINISTRATION OF ETHANOLIC LEAF EXTRACT OF CROTON ZAMBESICUS ON HEMATOLOGICAL PARAMETERS OF RATS
}

\author{
${ }^{*}$ J. E. OKOKON, K. C. IYADI, C. O. EFFIONG, \\ Department of Pharmacology \& Toxicology, faculty of pharmacy, University of Uyo, Uyo, Nigeria.
}

Summary: Ethanolic leaf extract of Croton zambesicus was administered to rats at doses of $100-$ $400 \mathrm{mg} / \mathrm{kg}$ for 21 days to investigate its effect on the haematological indices of rats. Haematological indices, namely packed cell volume (PCV), Haemoglobin concentration (Hb) Red blood cell count (RBC), Mean cell Haemoglobin concentration (MCHC), Mean cell volume (MCV), and Mean Corpuscular Haemoglobin (MCH) were assessed from whole blood obtained from the treated animals as well as those in the control group. The extract at the doses administered was found to caused reductions in PCV, HB, RBC, MCH, MCH and WBC, in a dose - dependent fashion. However elevation of MCV was observed. This results indicate that the extract has the potential of suppressing haemopoiesis and causing anaemia.

Key Words: Croton zambesicus, haemotological indices, anaemia, rats.

\section{Introduction}

Croton zambesicus Muell Arg. (Euphorbiaceae) syn C. amabilis Muell. Arg.; syn. C. gratissimus Burch), is an ornamental tree grown in villages and towns of Nigeria. It is a Guineo - Congolese species widely spread in tropical Africa. The leaf decoction is used in Benin as anti hypertensive and antimicrobial (urinary infections)( Adjanohoun et al, 2002). The Ibibios in Uruan Area of Akwa Ibom State use the leaf traditionally as malaria remedy. Block et al (2002) reported that ent - trachyloban $3 \beta$ - ol, a trachylobane diterpene, isolated from dichloromethane extract of the leaves has cytotoxic activity on Hela cells. The alkaloidal fractions of the leaf have been reported to possess a weak activity against Klebsiella pneumoniae, Pseudomonas aeruginosa, Bacillis megaterium, Bacillus subtilis, Eschericia coli, Proteus mirabilis, Staphyloccocus aureus, Aspergillus niger, Microsporum species and Penicillium species (Abo et al 1999). The alkaloidal fractions of the stem have also been reported to be active against all micro- organisms mentioned above (Abo et al 1999). The essential oil found in the leaves contain P - cymene, linalool and beta - caryophyllene (Menut et al, 1995). The constituent of the essential oil also found in the flowering tops are pinene, limonene, linalool, methol, carvone, thymol, alpha humulene and ceisnerolidol (Mekkawi, 1985). The study was aimed at investigating the effect of repeated administration of ethanolic leaf extract of Croton zambesicus on haematological indices namely packed cell volume, haemoglobin concentration, red blood cell count, mean haemoglobin concentration, white blood cell count and subsequently to evaluate whether its ethnopharmacological uses particularly as malaria remedy may have possible side effects such as anaemia, which is common with the use of most chemotherapeutic agents.

\section{Materials and Methods}

Preparation of Plants Extract

The leaves of Croton Zambesicus Muell. Arg. (Euphorbiaceae) were collected August, 2003, from a compound in Uyo, Akwa Ibom State, and authenticated by Dr Uduak Eshiet, a taxonomist in the department of Botany, University of Uyo, Uyo Nigeria. Hebarium specimen was deposited at faculty of pharmacy hebarium University of Uyo, Uyo with voucher no. FPUU209.

The fresh leaves $(2 \mathrm{~kg}$ ) of the plant were dried on a laboratory table for 8 days and reduced to powder. The powder $100 \mathrm{~g}$ was macerated in ethanol (300ml) for 72 hours. The liquid extract obtained was concentrated in vacuo at $40^{\circ} \mathrm{C}$. The yield was $3.81 \%$. The extract was stored in a refrigerator at $4^{0} \mathrm{C}$ until used for experiments reported in this study.

\section{Animals}

The animals used in the study were young adult, male and females, (150- 180g) albino wistar rats obtained from University of Uyo animal house, Uyo, Nigeria. The animals were used after an acclimatization period of 10days to room temperature and relative humidity of $28 \pm 5^{0} \mathrm{C}$ and $50 \%$ respectively. The were housed in standard cages and 
maintained on standard animal pellets (Pfizer livestock feeds, Aba Nigeria) and water ad libitum.

\section{Experimental Design}

The rats were weighed and randomly assigned on the basis of weight into 5 groups of 5 animal each. Animals in Groups A, B, C and D were orally administered with 400, 300, 200 and $100 \mathrm{mg} / \mathrm{kg}$ of the extract respectively, while animals in group $\mathrm{E}$ were orally given normal saline $5 \mathrm{ml} / \mathrm{kg}$ and served as control. Administration of the extract continued for 21 days between 0.8.00 and 0.9:00 hour each day. Twenty four hours after the last administration, the animals were anaesthetized with chloroform vapour and dissected. Whole blood was obtained by cardiac puncture from each rat and collected into anticoagalant - treated (EDTA 0. 77M) sterile bottles. This was used for haematological studies. Blood haemoglobin ( $\mathrm{Hb})$ was determined spectrophotometrically by the cyanomethaemoglobin method (Jain, 1986), packed cell volume (PCV) was determined by method of Jain, (1986). Red Blood Cell (RBC) count was estimated by haemocytometer method of Arowolo (1982). Blood was diluted in 1,200 Dacie's fluid which keeps and preserves the integrity of the RBC. For White Blood Cell (WBC) counts the dilution factor was 1:20 using $2-3 \%$ solution of acetic acid to which gentian violet was added.

The calculations for red cell indices were made as described by Jain (1986) Mean Corpuscular Volume $(\mathrm{MCV})=\mathrm{PCV} \times 10 / \mathrm{RBC}(\mathrm{fl})$

Mean Corpuscular Haemoglobin (MCH)

$=\mathrm{Hb} \times 10 / \mathrm{RBC}(\mathrm{pg})$

Mean corpuscular Haemoglibin concentration $=$ Hbc $\times 100 /$ PCV

\section{Statistical Analysis}

All data obtained were statistically analysed using students' t-test. The data were expressed as average mean \pm standard error and values of $\mathrm{P}<0.05$ were considered significant.

\section{Results}

The results of the effect of sub chronic administration of ethanolic leaf extract of Croton zambesicus on haematological indices of rats is presented in Table 1. Treatment of rats for 21days with the extract resulted in a dose- dependent reduction of PCV. The reduction was significant $(\mathrm{P}<$ 0.5 ) in group A with a value of $50.7 \pm 5.9 \%$ (mean \pm S.D) compared to control value of $56.7 \pm 4.8 \%$. The values for group B, C and D were $52.5 \pm 7.6,53.2 \pm 4.9$ and $55.3 \pm 2.5 \%$ respectively (Table 1 ). The blood haemoglobin concentrations (g/dl) were reduced in a dose - dependent fashion with significant $(P<0.05)$ decrease recorded in groups $\mathrm{A}$ and $\mathrm{B}$ relative to control. The values were $12.3 \pm 0.8,13.2 \pm 1.0,14.6$ $\pm 0.3,15.5 \pm 0.8$ and $16.0 \pm 0 \mathrm{~g} / \mathrm{dl}$ for groups A, B, C, $\overline{\mathrm{D}}$, and $\mathrm{E}$ respectively $\mathrm{A}$ non - significant $(\mathrm{P}<0.5)$ reduction in $\mathrm{RBC}$ counts of rats treated with the various doses of the extract was observed. The counts were $8.84 \pm 1.1,9.7 \pm 0.5,9.7 \pm 0.6,10.27 \pm 2.0$ millions per ml of blood respectively for groups $\mathrm{A}, \mathrm{B}$, $\mathrm{C}$ and D (Table 1), while the control group had a count of $10.6 \pm 0.63$ millions per $\mathrm{ml}$ of blood. There was a dose - dependent decrease in the value of MCHC calculated. A significant $(\mathrm{P}<0.05)$ decreased was recorded from rats in groups $\mathrm{A}$ with a value of $24.3 \pm 2.4 \%$ compared to control group with $28.22 \pm$ $1.0 \%$. The values were $25.14 \pm 1.2,27.4 \pm 0.9$ and $28.02 \pm 3.1 \%$ for groups B, C and D respectively. The calculated values of MCH showed a decrease compared to control in a dose - dependent fashion, although the differences were not significant. For groups $\mathrm{A}, \mathrm{B}, \mathrm{C}$, and $\mathrm{D}, \mathrm{MCH}$ values of $13.91 \pm 5.5$, $13.6 \pm 2.0,15.05 \pm 4.6$ and $15.06 \pm 3.0 \%$ were recorded respectively, while that of control group was 15.09 $\pm 1.0 \%$. Elevation of MCV values was observed. A significant $(\mathrm{P}<0.05)$ elevation was recorded in group A with a value of $57.35 \pm 0.6 \mu \mathrm{m}^{3}$ compared to control value of $53.49 \pm 0.4 \mu \mathrm{m}^{3}$. MCV values were $54.12 \pm$ $1.1,54.84 \pm 0.7$, and $53.74 \pm 1.0 \mu \mathrm{m}^{3}$ for groups $\mathrm{B}, \mathrm{C}$, and $\mathrm{D}$ respectively. The white blood cell counts (thousands $/ \mu \mathrm{l}$ ) for groups $\mathrm{A}, \mathrm{B}, \mathrm{C}$, and D were $7.7 \pm$ $3.3,9.0 \pm 0.8,13.8 \pm 0.6$ and $14.0 \pm 4.9$ respectively and the control had a counts of $14.7 \pm 6.0 / \mu \mathrm{l}$ of blood. The count was observed to reduce with increased doses. 
Table 1: Effect of Ethanolic leaf extract of Croton zambesicus on haematological indices of rats.

\begin{tabular}{|c|c|c|c|c|c|c|c|}
\hline $\begin{array}{l}\text { Haamatologica } \\
\text { l Parameters }\end{array}$ & $\begin{array}{c}\text { RBC } \\
\left(\mathrm{x} 10^{6} \mu \mathrm{l}\right)\end{array}$ & $\begin{array}{l}\text { PCV } \\
(\%)\end{array}$ & $\begin{array}{c}\mathrm{Hb} \\
\text { (g/ dl) }\end{array}$ & $\begin{array}{c}\text { MCHC } \\
(\%)\end{array}$ & $\begin{array}{l}\mathrm{MCH} \\
\text { (pg)0 }\end{array}$ & $\begin{array}{l}\mathrm{MCV} \\
\left(\mu \mathrm{m}^{3}\right)\end{array}$ & $\begin{array}{l}\text { TOTAL WBC } \\
\left.\text { (x } 10^{3} \mu \mathrm{l}\right)\end{array}$ \\
\hline Treatment & & & & & & & \\
\hline $\begin{array}{l}\text { GROUPS A } \\
(4000 \mathrm{mg} / \mathrm{Kg})\end{array}$ & $8.84 \pm 1.1$ & $50.7 \pm 5.9$ & $12.3 \pm 2.4$ & $\begin{array}{c}24.3 \pm \\
0.8\end{array}$ & $13.9 \pm 5.5$ & $57.35+0.6$ & $7.7 \pm 3.3$ \\
\hline $\begin{array}{l}\text { GROUPS B } \\
\text { (300mg/kg) }\end{array}$ & $9.7 \pm 0.5$ & $52.5 \pm 7.6$ & $13.2 \pm 7.6$ & $\begin{array}{l}25.14 \\
+1.2\end{array}$ & $13.6 \pm 2.0$ & $54.12 \pm 1.1$ & $9.0 \pm 10.8$ \\
\hline $\begin{array}{l}\text { GROUPS C } \\
(200 \mathrm{mg} / \mathrm{kg})\end{array}$ & $9.7 \pm 0.6$ & $53.2 \pm 4.9$ & $14.6 \pm 0.3$ & $\begin{array}{c}27.4 \pm \\
0.9\end{array}$ & $\begin{array}{c}15.05 \pm \\
4.6\end{array}$ & $54.84 \pm 0.7$ & $13.8 \pm 0.6$ \\
\hline $\begin{array}{l}\text { GROUPS D } \\
(100 \mathrm{mg} / \mathrm{kg})\end{array}$ & $10.29+2.0$ & $55.3 \pm 2.5$ & $15.5 \pm 0.8$ & $\begin{array}{c}28.02+ \\
3.1\end{array}$ & $\begin{array}{c}15.0 .6 \pm \\
3.0\end{array}$ & 53. $74+1.0$ & $14.0 \pm 4.9$ \\
\hline $\begin{array}{l}\text { GROUP E } \\
\text { (Control) }\end{array}$ & $10.6 \pm 0.6$ & $56.7 \pm 4.8$ & $16.0 \pm 0.0$ & $\begin{array}{c}28.22 \pm \\
1.0\end{array}$ & $\begin{array}{c}15.09 \pm \\
1.0\end{array}$ & $53.49 \pm 0.4$ & $14.7 \pm 6.0$ \\
\hline
\end{tabular}

\section{Discussion}

Administration of ethanolic leaf extract of Croton Zambesicus to rats for 21 days produced a dose dependent reduction in $\mathrm{PCV}, \mathrm{Hb}, \mathrm{RBC}, \mathrm{MCHC}, \mathrm{MCH}$ and WBC. Elevation of MCV values of the treated rats was also recorded. The dose dependent reduction in PCV, $\mathrm{Hb}$ and $\mathrm{RBC}$ may have resulted from hemolytic activity of the extract leading to the observed reduction. It could also be a result of suppressive action of the extract on erythropoiesis. These reductions result in anaemic condition. Keele et al (1983) reported that normocytic, hypochronic anaemia results when there is a reduction in $\mathrm{MCHC}$ and $\mathrm{MCH}$, while MCV as normal. A similar case was observed in this study though the MCV values are slightly elevated. Total white blood cells were observed to have reduced following the administration of the extract to rats. The decrease observed may have resulted from suppression of leucocytosis by the extract and also from the suppression of their production in the bone marrow. Further studies to confirm this as well as evaluate its mechanism of action are suggested.

\section{Acknowledgment}

The authors are grateful to Mr Nsikan Malachy of Dept. of Pharmacology and Toxicology, University of Uyo for his technical assistance.

\section{References}

Adjanohaun, E. J., Adjakidje, V. and de Souza, S. (1989) Contribution to Ethnobotainical and Floristic Studies in Benin Republic Vol. 1. Agency for Cultural and Technical Cooperation. P. 245.

Abo, K. A. Ogunleye, Ashidi, J. S (1999) Antimicrobial Potential of Spondias mombin, Croton zambesicus, and Zygotritonia crocea. Phytotherapy Research. 13 (6) 494 - 497.

Block, S. Stevigny, C; De Pauw - Gillet, M. C; de Hoffman, E. Llabres, G. Adjakidje, V. and Quetin - Lectercq, J. (2002) ent - Trachyloban - 3 - 
ol, a New Cytotoxic Diterpene from Croton zambesicus . Planta Medica. 68. 647 - 648.

Jain, N. C. (1986) Veterinary Haematology (Jain N C Ed) Lea and Ferbiger, Philadelphia.

Keele, C. A., Neil, and Joels, N. (1983) Sampson Wright's Applied Physiology. $13^{\text {th }}$ ed, Oxford University Press.
Mekkawi, A C, (1985) The Essential Oil of Croton zambesicus Fitoterapia 56 (3) : 181 - 183.

Menut, C; Lamaty, G; Bessiere J. M: Suleiman, A. M; Fendro, L; Maidou, E and Denamgania, J. (1985). Aromatic Plants of Tropical Central Africa. Journal of Essential Oil Research. 7 (4): 419 422.

Received: June 21, 2004

Accepted: August $1^{\text {st }}, 2004$ 